\title{
Monetary Growth and the Timing of Interest Rate Movements
}

\author{
W. W. BROWN and G. J. SANTONI
}

"W

$\mathrm{T}$ IS widely believed that market interest rates follow a particular time path in response to changes in the rate of monetary growth. This time path is important because interest rates are thought to be one of the conduits of monetary policy.

In particular, an unanticipated but permanent increase in the monetary growth rate will presumbly lower market interest rates, temporarily resulting in a reshuffling of resources among competing uses. As a consequence, an economy characterized by slack will be pushed to a permanently higher lev el of aggregate demand, employment, output and, eventually, higher market interest rates as a result of the monetary stimulus.

The length of the time path followed by interest rates reveals information concerning the lag in monetary policy's effect. Curiosity about this provided the initial motivation for earlier empirical investigations. ${ }^{1}$ This paper discusses the theoretical argument and examines some evidence regarding the response of interest rates to changes in monetary growth.

W. W. Brown is an associate professor of economics at California State University, Northridge.

"William E. Gibson, "Interest Rates and Monetary Policy,"Journal of Political Economy (May/June 1970), pp. 431-55; Burton Zwick, "The Adjustment of the Economy to Monetary Changes," Journal of Political Economy (January/February 1971), pp. 77-96. Phillip Cagan, Changes in the Cyclical Behavior of Interest Rates (National Bureau of Economic Research, Occasional Paper 100, 1966); William E. Gibson and George E. Kaufman, "The Sensitivity of Interest Rates to Changes in Money and Income, Journal of Political Economy (May/June 1968), pp. 472-78; Phillip Cagan and Arthur Gandolfi, "The Lag in Monetary Policy as Implied by the Time Pattern of Monetary Effects on Interest Rates," The American Economic Review, Papers and Proceedings (May 1969), pp. 277-84; Phillip Cagan, The Channels of Monetary Effects on Interest Rates (National Bureau of Economic Research, 1972); Michael Melvin, "The Vanishing Liquidity Effect of Money on Interest: Analysis and Implications for Policy," Economic Inquiry (April 1983), pp. 188-202.

\section{TER THORY}

Equation 1 breaks the nominal interest rate, $i_{\text {, into }}$ its two components: the ex ante real interest rate, $\mathrm{r}$, and the expected rate of inflation, $\dot{\mathrm{P}}_{\mathrm{e}}$.

(1) $\mathbf{i}=r+\dot{\mathrm{P}}_{\mathrm{e}}$

The waxing and waning of the effects of a change in monetary growth on each of these components generates the time path followed by the nominal rate. An unanticipated change in monetary growth initially affects the ex ante real rate of interest; this is called the "liquidity effect."2 The permanent change in monetary growth, once it is known, affects the expected rate of inflation and is called the "Fisher effect."

\section{The Liquinty nect}

The theoretical argument concerning the liquidity effect typically runs as follows: an unanticipated increase in the monetary growth rate results initially in an excess supply in the money market at the existing nominal rate of interest. Part of this excess shows up as an increase in the demand for securities. The prices of securities are bid up, and nominal yields decline until the market clears. ${ }^{3}$

\footnotetext{
${ }^{2}$ Traditionally, the term "liquidity effect" was used to describe the impact of an unanticipated change in the stock of money on interest rates. More recently, however, the term has been applied to the initial effect on interest rates of an tnanticipated change in the stock of money induced by an unanticipated change in the monetary growth rate. We have adopted the more recent usage of the term in this paper. Milton Friedman, "Factors Affecting the Level of Interest Rates, "Money Supply, Money Demand, and Macroeconomic Models, J. T. Boorman and T. M. Havrilesky, eds. (Allyn and Bacon, Inc., 1972), pp. 205-06.

${ }^{3} \mathrm{See}$, for example, Cagan, The Channels of Monetary Effects. Note, particularly, that "the first round effects of money creation are ignored ...."(p. 85)
} 
Coincident with the downward movement of nominal yields in the loanable funds market is a reduction in the ex ante real rate of interest in the goods market. The result is that investment demand is stimulated and saving out of current income is reduced. The contention is that real investment and consumption rise, stimulating economic activity. The excess demand for real present resources that follows from this decline in the ex ante real rate is made up by "the flow of funds supplied out of the discrepancy between actual and desired money balances. . . ."4

After a sufficient time, the excess supply in the money market is eliminated by an expansion in nominal income. This expansion raises the demand for money, reverses the liquidity effect and returns the $e x$ ante real interest rate to its original level.

\section{The Fisher Effect}

A permanent increase in the monetary growth rate will result in a permanently higher rate of inflation, ceteris paribus. Since lending contracts typically specify fixed nominal payment streams, a higher nominal rate will be required to compensate lenders for the increased rate of depreciation expected to occur in the real value of their receipts. If credit market particim pants acquire information regarding the permanently higher rate of inflation with a lag, the convergence of the nominal rate upon a higher level will occur gradually with a corresponding lag.

\section{An Illustration of the Time Path}

Figure 1 depicts hypothesized time paths of the ex ante real rate of interest, $r$ (panel $A$ ), the expected rate of inflation, $\dot{\mathrm{P}}_{\mathrm{e}}$ (panel $\mathrm{B}$ ), and the nominal rate of interest, $i$ (panel $C$ ), that result from an unanticipated and permanent increase in the monetary growth rate beginning at time $\mathrm{t}_{0}$.

Assuming that the expected rate of inflation and the price level do not immediately adjust to the change in monetary growth, the ex ante real rate of interest moves along a path like abc and remains below its initial level until time $t_{3}$. The liquidity effect is illustrated by the movement from a to $b$; the expansion effect is shown by the movement from $\mathrm{b}$ to $\mathrm{c}$.

Panel B of figure 1 illustrates the time path of the expected rate of inflation. Given the lag in the acquisition of information concerning the permanently higher

${ }^{\ddagger}$ Tbid., p. 87.

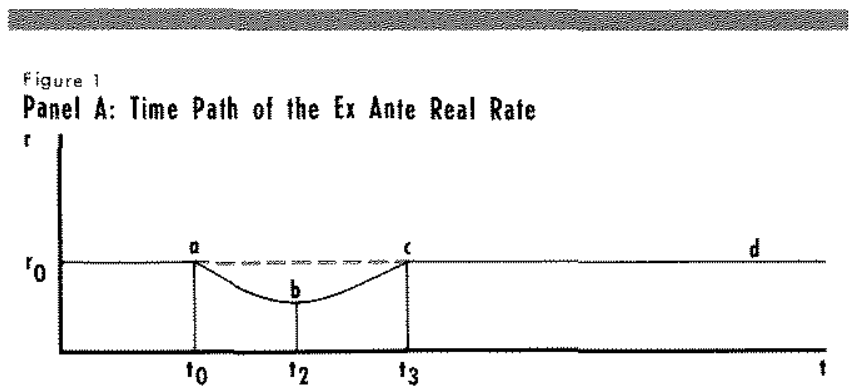

Panel B: Time Path of Expected Inflation

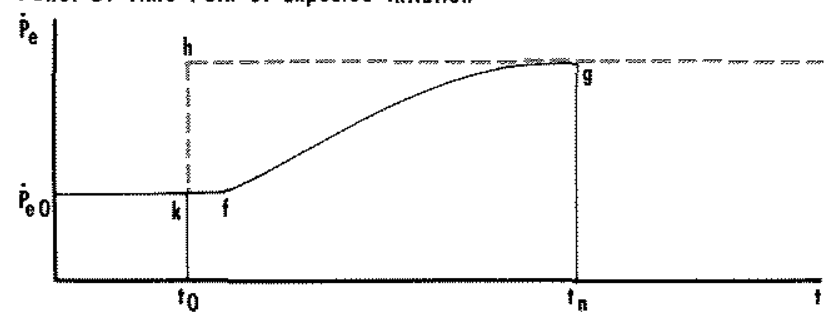

Panel C: Time Patl of the Nominal Rate

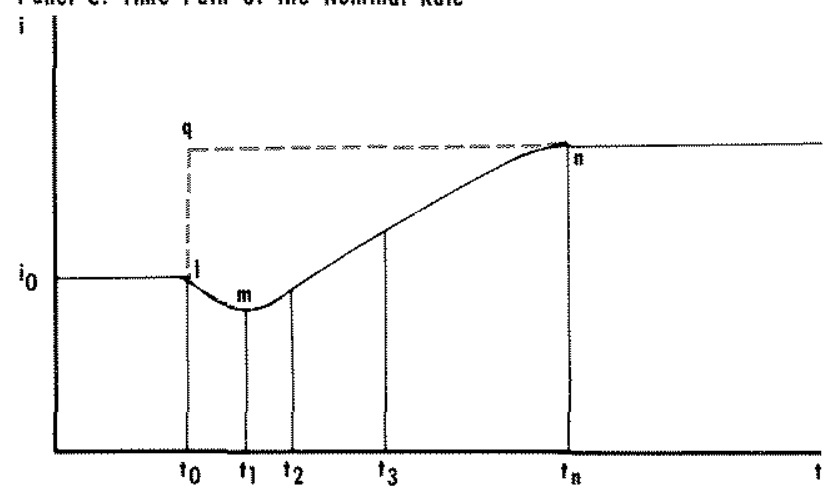

rate of monetary growth, the expected rate of inflation is presumed to adjust along a path like kfg. This is the Fisher effect.

Panel $\mathrm{C}$ presents the time path of the nominal interest rate. It is derived by adding the time path of the expected rate of inflation to the time path of the ex ante real rate of interest as suggested by equation 1 to obtain the path $I \mathrm{mn}$. Note that the nominal rate reaches a minimum in period $t_{1}$, which is both higher and occurs earlier than the minimum of the ex ante real rate.

The path of the nominal rate depends on how swiftly the expected rate of inflation responds. ${ }^{5}$ It is possible

\footnotetext{
${ }^{5}$ We assume that nominal rates adjust perfectly to changes in expected inflation as suggested by Fisher's theory. For further discussion of this issue, see John A. Carlson, "Short-Term Interest Rates as Predictors of Inflation: Comment," American Economic Review (June 1977), pp. 469-75; Jan Watter Elliot, "Measitring the Expected Real Rate of Interest: An Exploration of Macroeconomic Alternatives," American Econonic Review (June 1977), pp. $429-$ 44; Eugene F. Fama, "Short-Term Interest Rates as Predictors of Inflation," American Economic Review (June 1975), pp. 269-82.
} 
that the nominal rate will fail to decline in response to an increase in the monetary growth rate even though the $e x$ ante real rate does. In the extreme, if expectations and the price level were to adjust perfectly and instantaneously to the permanent increase in monetary growth at $t_{0}$, there would be no liquidity effect. An excess supply of money, which is a precondition for the operation of a liquidity effect, would not exist. The expected rate of inflation and the nominal rate would move along the paths khg and lqn, respectively.

\section{AN ECONOMIC CONST TAN ON ON THE TUME PATI}

Theory provides little guidance in identifying the actual time paths that are followed by the nominal and $e x$ ante real interest rates. This can only be resolved empirically. The time paths that interest rates follow when adjusting to a change in monetary growth will be constrained, however, by the wealth-maximizing behavior of individuals. The time paths must be such that they cannot be predicted (ex ante) by market participants.

\section{Effoient Markets and the Response of the Nominal Fate}

On an intuitive level, a systematic and predictable relationship between the nominal interest rate and changes in the monetary growth rate that are known to be permanent (like that shown by the path $\operatorname{lmn}$ in panel C of figure 1) may imply that profitable trading opportunities are left unexploited by financial market participants. ${ }^{6}$ If transaction costs are low relative to the predicted change in the value of the security traded, selling, and selling short at $t_{0}$, will result in trading profits. Naturally, such trading would tend to eliminate the lag in the adjustment of nominal interest rates, causing the time path to move toward one like lqn. ${ }^{7}$

\footnotetext{
This point was discussed by Fisher in 1896 . "If gold appreciates in such a way or in sach a sense that he (the ordinary man) expects a shrinking margin of profit, he will be cautious about borrowing unless interest falls; and this very unwillingness to borrow, lessening the demand in the 'money market' will bring interest down." Further, "every chance for gain is engerly watched. An active and intelligent speculation is constantly going on, which. . . performs a well-known and provident social function for society. Is it reasonable to believe that foresight, which is the general rule, has an exception when applied to falling or rising prices?" Irving Fisher, "Appreciation and Interest," Publications of the American Economic Association (August 1906), pp. 36-37.

${ }^{7}$ Eugene F. Fanra, "Efficient Capital Markets: A Review of Theory and Empirical Work," The Journal of Finance, Papers and Pro-
}

The acquisition of new information, of course, is costly and these costs may increase with the rate of acquisition. Under these circumstances, interest rates will adjust to changes in monetary growth with a lag. The length of the lag will depend upon the relative costs and benefits of acquiring information more rapidly.

\section{Whoion Wurkets and the Fah of the Real Rate}

Since the ex ante real rate of interest reflects the value of present consumption (short-lived, nondurable goods) relative to future consumption (long-lived, durable goods), the liquidity effect implies a specific time path of the relative prices of long- in terms of shortlived goods. In particular, the time path of the ex ante real rate in panel $A$ of figure 1 suggests that the prices of more durable goods (long-lived assets) rise relative to less durable goods (short-lived assets) from $t_{0}$ to $t_{2}$, then fall to their "normal" levels from $t_{2}$ to $t_{3} .{ }^{8}$

Our previous comments regarding the limits to profitable bond trading apply as well to the predictability of this U-shaped pattern in the prices of long- and shortlived assets. That is, predictable U-shaped swings in the relative prices of various assets (as implied by the time pattern of the real rate shown in panel A of figure 1) may indicate that profitable trading is possible in

ceedings (May 1970), pp. 383-417; and Frederic S. Mishkin, A Rational Expectafions Approach to Macroeconometrics (National Bureau of Economic Research, 1983).

${ }^{8}$ As an exarnple, see Milton Friedman's discussion. He reasons that "from a longer-term view, the new balance sheet (of the public) is ont of equilibrium, with cash being temporarily high relative to other assets. Holders of cash will seek to purchase assets to achieve a desired structure. This will bid up the price of assets . . . These effects can be described as operating on 'interest rates, if a more cosmopolitan interpretation of 'interest rates' is adopted than the usual one which refers to a small range of marketable securities.

"The key feature of this process is that it tends to raise the pricess of sources of both producer and consumer services relative to the prices of the services themselves . . . It therefore encourages the production of such sources (this is the stimulus to 'investment' . . ) and, at the same time, the direct acquisition of services rather than of the source (this is the stimulus to consumption' relative to 'savings"). But these reactions in their tura tend to raise the prices of services relative to the prices of sources, this is, to undo the initial effects [our emphasis] on interest rates.

"Of course, all these forces operate simultaneously [our empha" sis] and there are ebbs and flows and not merely movement in one direction." Milton Friedman, "The Lag in Effect of Monetary Policy," in Milton Friedman, ed., The Optimum Quantity of Money and Other Essays (Aldine Publishing Co., 1970), pp. 25556. 
these markets. As in financial markets, however, such trading will tend to limit these changes in relative prices to magnitudes that essentially reflect the cost of transacting. ${ }^{9}$ In short, the time paths of both real and nominal interest rates will be constrained by the existence of efficient financial and capital markets. ${ }^{10}$

\section{SEATCHNG FOP A VALD TUST Prentor}

The conditions that must exist to generate a time path of interest rates like that shown in panel $C$ of figure $I$ are not trivial. Since the time path presumably is generated by a monetary policy shock, the institutional environment must be one that allows these shocks to occur. In particular, the operation of a Fisher effect will be especially sensitive to the implications the existing monetary institutions have for the expected duration of changes in the monetary growth rate and the possibility that these changes can be induced by the fiat of the monetary authority. In short, the institutions must be such that exogenously determined changes in the monetary growth rate are possible. In addition, since the liquidity effect depends upon monetary changes being unanticipated, it will operate only during periods in which the monetary authority can cause unpredictable changes in money growth. ${ }^{\text {II }}$ A precondition of this is that changes in money growth are unrelated to prior movements in other economic variables, particularly, interest rates.

\footnotetext{
${ }^{9}$ See Frank H. Knight, "Unemployment: And Mr. Keyre's Revolıtion in Economic Theory," Canadian Journal of Economics and Political Science (1937), pp. 112-13; Frank H. Knight, "Capital, Time and the Interest Rate," Economica (August 1934), pp. 25786: Lloyd W. Mints, Monetary Policy for a Competitive Society (MeGraw-Hill, 1950), pp. 58-70: Gustar Cassel, "The Rate of Interest, the Bank Rate, and the Stabilization of Prices," in Readings in Monetary Theory (The Blakiston Company, 1951), pp 319 33; and Frank H. Knight, The Ethics of Competition (Books for Libraries Press, 1969), pp. 273-74.

${ }^{10}$ If the changes in relative prices that are described in footnote 8 always follow the same time sequence, it is possible that profitable trades are left unexploited. On the other hand, if "all these forces operate simultaneously," the possibility of wealth increasing exchange is eliminated but so is the time path of the ex ante real rate. As it stands, the argument appears to be ambiguous concerning the time path followed by the ex ante real interest rate.

"Frederic S. Mishkin, "Monetary Policy and Long-Term Interest Rates: Ar Efficient Markets Approach," Journal of Monetary Economics (January 1981), pp. 29-55; Frederic S. Mishkin, "Monetary Policy and Short-term Interest Rates: An Efficient Markets-hational Expectations Approach," The Journal of $\mathrm{Fi}$ nance (March 1982), pp. 63-72; David A. Pierce, "Relationships - and the Lack Thereof - Between Economic Time Series, with Special Reference to Money and Interest Rates,"Journal of the American Statistical Association (March 1977), pp. 11-22.
}

Unfortunately, data concerning anticipated and unanticipated money growth are not directly observable, and we know of no satisfactory method of empirically separating actual money growth into these two components. In addition, it is not generally possible to direct ly observe the ex ante real interest rate. For these reasons, the liquidity effect tends to be confounded by the Fisher effect in empirical tests. However, since one of our main purposes is to discover the lag in the effect of monetary policy as implied by the time path of nominal interest rates, this is not particularly troublesome.

In the following, we examine various historical periods during which different monetary institutions prevailed. Our purpose is to discover a period that will yield a valid test of the hypothesis concerning the time path.

\section{The cold sandard period $1900-29^{12}$}

The Gold Standard Act became law in March of 1900 and remained in force until January of 1934 when it was superseded by the Gold Reserve Act. During this period, the price of gold was fixed at $\$ 20.67$ per ounce and, equally important, gold circulated as a medium of exchange. Maintenance of this type of gold standard imposes binding constraints on the monetary authorities that prevent them from generating significant and long-lived changes in money growth (in the absence of new gold discoveries or improvements in mining technology). "The stock of money must be whatever is necessary to balance international payments." 13 Hence, any change in the growth rate of money that, if maintained, would cause the future supply of money to deviate from that necessary to maintain the balance of payments and the fixed exchange rate between the dollar and gold must eventually be offset by a change in the opposite direction.

During this period, individuals holding monetary assets, in large part, were insulated from changes in the real value of their assets. Under the gold standard, any unanticipated change in the general level of prices produced by temporary changes in the quantity of money "was likely to reverse or 'correct' itself, i.e.,

\footnotetext{
\$2 To avoid the confounding effects of the depression years, we have omitted them from our analysis.

${ }^{13}$ Milton Friedman and Anna Sehwartz, A Monetary History of the United States 1867-1960 (Princeton University Press, 1963), p. 191.
} 
'average out' over time."14 Friedman and Schwartz note that ". . the gold standard ruled supreme when the act (the Federal Reserve Act) was passed, and its continued supremacy was taken for granted. . .."15

Consequently, since changes in monetary growth were arguably viewed as temporary during this period, we would not expect to observe the Fisher effect.

While the gold standard prevented significant and long-lived changes in money growth, it did not prevent the occurrence of short-term swings in the growth rate. The coefficient of variation in the annual growth rate of money is 87 percent during the 1914-29 period. In contrast, during the $1970-82$ period, which has been characterized as a period of highly volatile money growth, the coefficient of variation is 20 percent.

Since the liquidity effect is a short-term phenomenon predicated on unanticipated changes in the monetary growth rate (whether permanent or temporary), this period would seem to be particularly appropriate in testing for its presence because the Fisher effect is arguably zero. Temporary changes in the growth rate of money did not induce confounding impacts on the nominal rate. Roughly, movements in nominal rates should mirror movements in real rates during the gold standard. ${ }^{16}$ If money is exogenous with

\footnotetext{
${ }^{14}$ Benjamin Klein, "Our New Monetary Standard: The Measurement and Effects of Price Uncertainty," Economic Inquiry (December 1975), p. 471; see, as well, I. B. Ibrahim and Raburn M. Williams, "The Fisher Relationship Under Different Monetary Standards," Journal of Money, Credit and Banking (August 1978), pp. 363-70. In addition, the major discoveries of gold had ocm eurred prior to 1900 and the cyanide process was successfully applied to gold mining in the $1890 \mathrm{~s}$.

${ }^{15}$ Friedman and Schwartz, A Monetary History, p. 191.

${ }^{16}$ One right question whether changes in the nominal rate tracked changes in the real rate of interest during this period. To check this, we regressed annual changes in the yield of high grade corporate bonds (Standard and Poor's) on annual changes in the ratio of the Consumer Price Index divided by an index of stock prices (Standard and Poor's) for the period 1907-29. Given Klein's evidence, changes in the bond yield daring this period should reflect changes in the real interest rate. The CPI, of course, is heavily weighted in the favor of present consumption goods and thus represents the average price of current consumption. The stock price index is an index of the prices of capital goods. Changes in the ratio of these two prices will track changes in the real rate of interest and be refected by changes in the bond yield during the gold standard period. The results are given below (t-values in parentheses):

$$
\begin{aligned}
& \Delta \mathrm{i}=.05+16.01 \Delta(\mathrm{CPI} / \mathrm{STDP}) \\
&(5.97) \\
& \mathrm{R}^{2}=.59 \mathrm{DW}=1.81
\end{aligned}
$$
}

The results are consistent with the claim that changes in bond yields reflected changes in the real rate of interest during this period.

Interestingly, the relationship breaks down completely for the more recent period, 1954-82. The results for this period are: respect to interest rates and if not all of the changes in monetary growth that occurred were anticipated, then the estimated relationship for this period should depict a time path of interest rates similar to that shown in panel A of figure 1 .

\section{The End of the Gold Standard Ack Through the korean War: 1934-53}

From mid-1934 through March of 1953, little variation occurred in short-term interest rates. For example, table 1 lists the level of the commercial paper rate and the number of months during which the rate remained constant at a particular level. The table indicates that the recorded commercial paper rate changed only four times during the period running from June 1934 through June 1938 and that, during this time, it remained constant at .75 percent for a period of 26 months. In fact, month-to-month changes in the recorded commercial paper rate were zero in all but 46 of the entire 225 months. In contrast, for the period $1954-82$, the rate failed to change in only 25 out of 348 months.

Since there was little month-to-month variation in either the commercial paper rate or other interest rates during the 1934-53 period, and since there is reason to believe that money was endogenous to interest rates during this period, we have treated it separately in the empirical tests. ${ }^{17}$

\section{The Korean war to the Present: $1934-82$}

Since the end of the Korean War, month-to-month variation in nominal interest rates has been considerable. The Gold Reserve Act, however, continued to tie the dollar, albeit loosely, to gold until August 15, 1971 . Consequently, we have split the $1954-82$ period at this point. During the latter period, the behavior of the monetary authority has been free of the formal constraints imposed by gold. If a relationship similar to that shown in panel $\mathrm{C}$ of figure 1 exists between money and interest rates, it should show up during this period.

$$
\begin{aligned}
& \Delta \mathrm{i}=.38+.54 \Delta(\mathrm{CPU} / \mathrm{STDP}) \\
& \mathrm{R}^{2}=.15 \quad \stackrel{(.98)}{\mathrm{RHO}}=.33 \quad \mathrm{DW}=\mathbf{1 . 6 2} \\
& \text { (1.84) }
\end{aligned}
$$

For further evidence, see Robert J. Shiller and jeremy J. Siegel, "The Gibson Paradox and Historical Movements in Real Interest Rates," Journal of Political Economy (October 1977), p. 905.

${ }^{17}$ Friedman and Schwart, A Monetary History, p. 562. 


\section{EMPIRICL ISTMATON}

Using monthly nominal interest rates and money supply data, we have run regressions for each of the subperiods 1914-29, 1934-53, 1954-70 and 1971-82. In each case, the money supply is defined as M1 balances. ${ }^{18}$ The interest rate is defined as the commercial paper rate (4-6 month maturity prior to November 1979 and 120-day maturity after). In each period, the monthly change in the interest rate is regressed on monthly changes in the rate of monetary growth in the contemporaneous month and 38 past (lagged) monthly changes. ${ }^{19}$ This specification initially was identified as the unrestricted model. In order to determine whether the estimated coefficients are sensitive to the lag length and to identify statistically redundant lags, the structure was shortened to $24,18,12,6,3,1$ and zero months. At each stage, an F-test was applied to determine whether the omitted lags were significant. ${ }^{20}$

\section{July 1914 - December 1929}

Table 2 presents the results for the $1914-29$ period. The test for lag length revealed a lag structure of three months. All of the estimated coefficients are negative, and three are significantly different from zero. The sum over the coefficients is significantly negative as well. These results suggest that a one percentage-point (100 basis-point) increase in the monetary growth rate would have produced a decline of about one basis point in the commercial paper rate during this period. ${ }^{21}$ Empirically, the estimated effect is surely miniscule and, as indicated by the F-statistic (2.08), we cannot reject the hypothesis that the relationship arose randomly. The constant term in the regression is statistically insignificant, which is consistent with the efficient

\footnotetext{
Wh balances wete emplored since brokdes monetary aggregates are nore likely to be endogenous with respect to interest rates. While the United States was on a gold standard prior to 1914 monthy MI data are not avalable before June 1914.

${ }^{15}$ This lag length was selected as a point of departure and is based tupon earlier work concerning the time path. See Cagan and Gindolf, "The Lag in Monetary Policy."

This test is sensitive to the initial lag length specified in the urrestricted model. As a consenuence it is possible that the test will reject some variables that are, in fact, significant if too long a lag is specified. To control for this, we ran the tests with the lag length in the unrestricted model initially set at 38 . We then reduced the number of lags in the unrestricted model to 24 and ram the test again. This was continued mintil we exhansted all of the possibilities.

${ }^{2}$ For funther hiscussion regarding this process, see Cagan and Gandolfi, "The Lag in Monetary Policy," p. 280
}

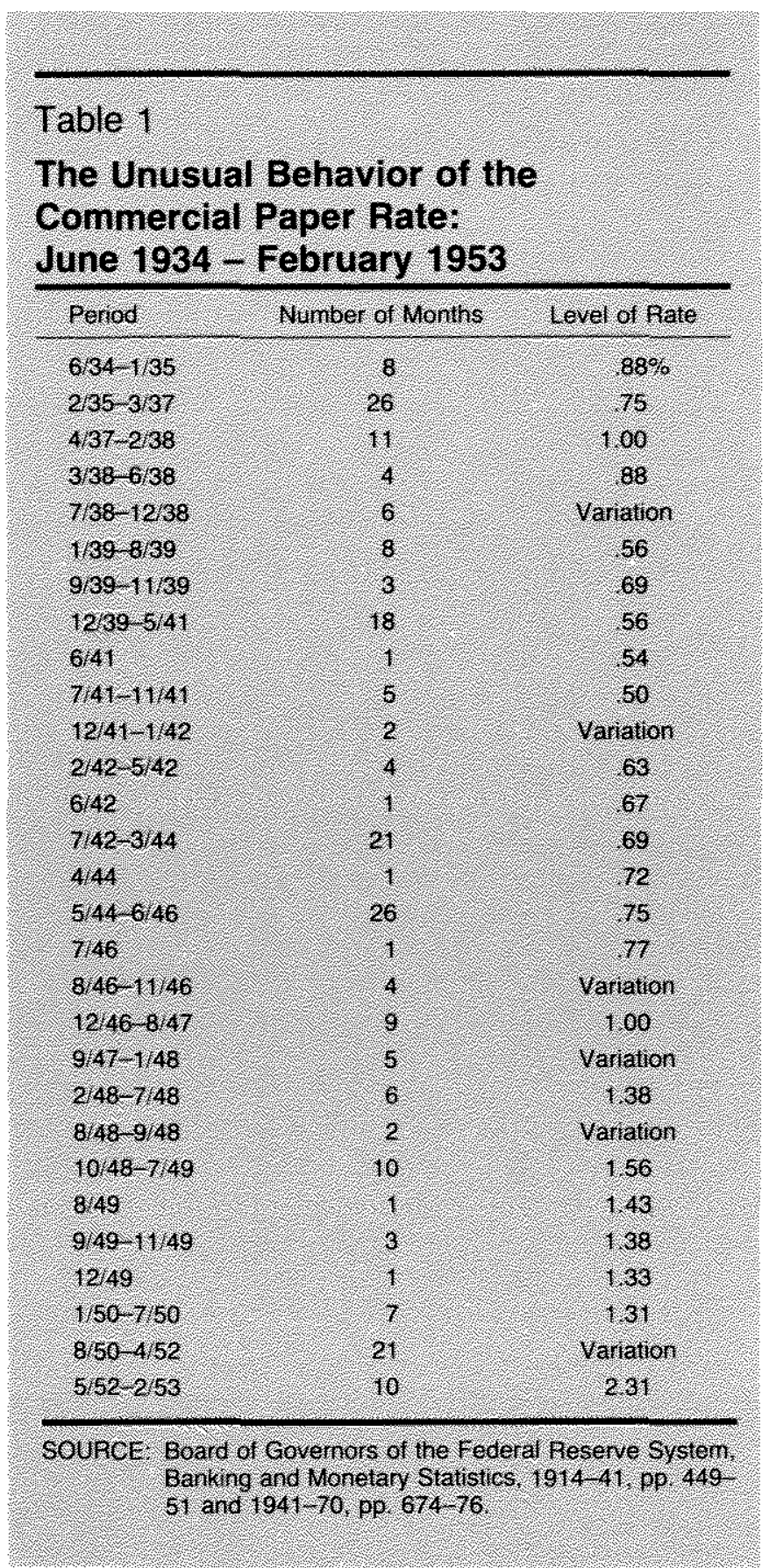

market hypothesis that interest rate changes have no trend.

Further, the results for this period are consistent with a long-ren Fisher effect of zero. This result was expected, given the constraints implied by the gold standard.

Applying a Granger "causality" test, we examined the data to determine whether changes in the interest rate are endogenous to changes in monetary growth, 
Table 2

The Relationship Between Changes in Money Growth and Changes in Interest Rates: July 1914 - December 1929

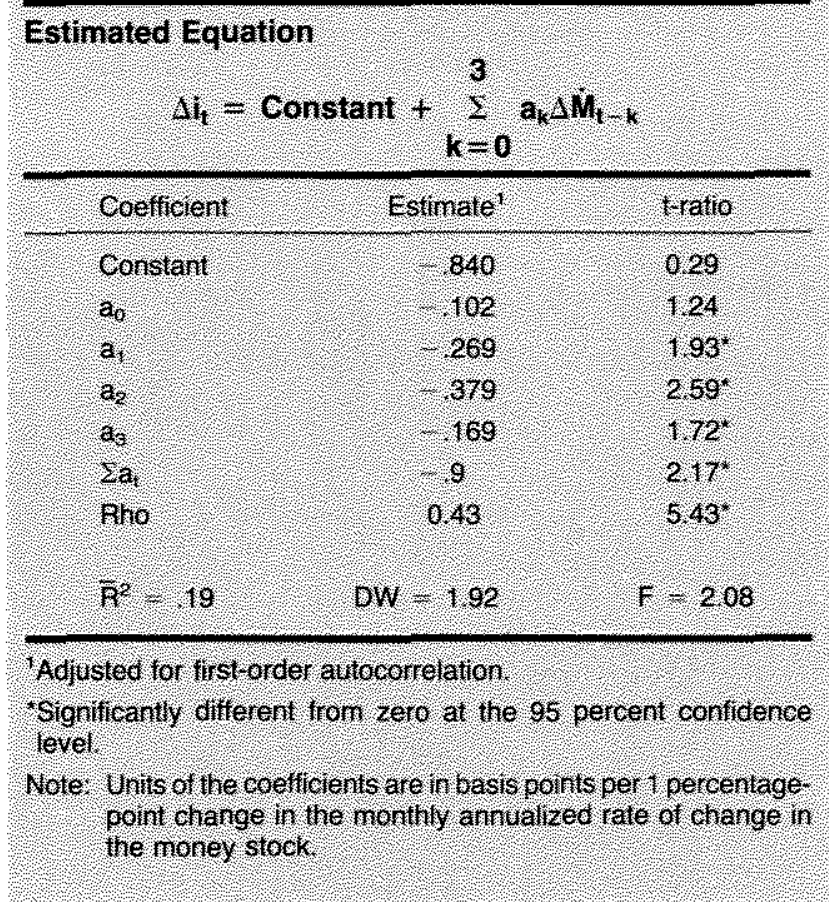

while changes in monetary growth are exogenous to changes in the interest rate. Lag lengths of $3,6,9,12$ and 18 months were used in the test. Our results, presented in table 3 , reject the hypothesis that changes in the monetary growth rate caused changes in the interest rate during this period.

On the whole, the results from the gold standard period are disappointing. We had hoped that they would provide some insight regarding the timing and magnitude of the liquidity effect. The table 2 results, however, are far from statistically impressive. They indicate a negligible, at best, liquidity effect. This, of course, is consistent with otr expectations, given efficient markets, but the interest rate does not return to its original level as predicted and the causality tests suggest that the changes in monetary growth that occurred during the period did not "cause" changes in the interest rate.

\section{Wandry 1934 - Decenber 1953}

Table 4 presents our results for the commercial paper rate during the 1934-53 period. As expected,

\begin{tabular}{|c|c|c|c|}
\hline Peniod & Lags & $\begin{array}{l}\text { F-statistic } \\
-1(\Delta M)\end{array}$ & $\begin{array}{l}\text { F-statistio } \\
\Delta \mathrm{M}-\phi(\Delta)\end{array}$ \\
\hline \multirow[t]{4}{*}{$7 / 1914-12 / 1929$} & a & 693 & 121 \\
\hline & 6 & 1.46 & 0.83 \\
\hline & 9 & 1.69 & $200 *$ \\
\hline & 12 & $9 \begin{array}{l}50 \\
4\end{array}$ & $\begin{array}{l}2.43^{*} \\
62\end{array}$ \\
\hline \multirow{5}{*}{$111934-12 / 1953$} & 3 & 0.26 & 0.00 \\
\hline & 6 & 0.44 & 0.59 \\
\hline & 9 & 0.48 & 658 \\
\hline & 12 & 0.00 & 057 \\
\hline & 18 & 0.40 & 0.47 \\
\hline \multirow{6}{*}{$1 / 1954-12 / 1970$} & 3 & 0.71 & $3.28^{*}$ \\
\hline & 6 & 1.21 & $5.01^{t}$ \\
\hline & 9 & 158 & $3.34^{*}$ \\
\hline & 12 & 1.62 & $2.99^{\circ}$ \\
\hline & 18. & 1.37 & $2.50^{*}$ \\
\hline & 24 & $\begin{array}{l}1.25 \\
1.24\end{array}$ & $2.44^{*}$ \\
\hline \multirow[t]{5}{*}{$11971-2 / 1983$} & 3 & $14.97^{\circ}$ & $19.50 \%$ \\
\hline & 6 & $14.32 \%$ & 973 \\
\hline & 9 & $974^{\circ}$ & $5.22 \%$ \\
\hline & 12 & 8.84 & $4.31 \%$ \\
\hline & 18 & $64^{\circ}$ & $2.79^{\circ}$ \\
\hline
\end{tabular}

tSignificantly diferent trom zero at he 95 percent contidence level.

due to the lack of variation in market rates, no relationship appears to exist between changes in the monetary growth rate and interest rates. None of the lags were significant in the F-tests. As a consequence, table 4 only reports the regression for the change in monetary growth contemporaneous to the change in the interest rate. Even in this case, we cannot reject the hypothesis that the constant and the coefficient of the change in monetary growth are zero.

The results of the Granger tests indicate that the money and interest rate series were independent during the period. This held for each lag length used in the test (see table 3).

\section{January 1954 - Docember 1970}

Our results for the January 1954 - December 1970 period are presented in table 5 . The lag structure indicated by the $\mathrm{F}$-test contains 24 months and, as in earlier periods, the constant is insignificant. These results generally are not consistent with the appear- 
Table 4

\section{The Relationship Between Changes in Money Growth and Changes in Interest Rates: January 1934 - December 1953}

\section{Estimated Equation}

$$
\lambda_{1}=\text { constant } t \text { a } A_{1}
$$

\begin{tabular}{|c|c|c|}
\hline Coefrorai & testruate & $(4+1)$ \\
\hline Constant & 38 & 170 \\
\hline$a_{0}$ & 0900,5 & 0014 \\
\hline 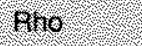 & 42 & 7.17 \\
\hline $72 \times-18$ & bw 200 & $f=.0 .00$ \\
\hline
\end{tabular}

Adusted tor irst-order aurocorretation:

S Suniticanly diferent from zero at we 95 percent contidence tevel

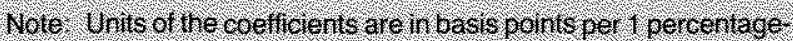
point change in the nonthly annualized tate of ehange in the noney slock

ance of either a contemporaneous or lagged liquidity effect in nominal interest rates. While the first four coefficients are negative, they are statistically indistinguishable from zero.

With the exception of lag 24 , the remaining coefficients are all positive and 15 are significant. Their sum (36.00 basis points) differs significantly from zero, which is consistent with the Fisher effect. The upward adjustment of the interest rate, however, is less than that implied by the Fisher effect. ${ }^{22}$

The results of the Granger test suggest that changes in the interest rate are exogenous to changes in the monetary growth rate, while changes in the monetary growth rate are endogenous to changes in the interest rate (see table 3 ). This result held up for each of the lag lengths employed. It appears that the causality relationship is one-way, running from interest rates to money. The theoretical arguments that underpin the hypothesis regarding the time path, however, are based on the assumption that money causes interest rates.

${ }^{22}$ We have little faith in the results obtained during this period. Unlike the other periods we consider, the F-test for lag length is particularly sensitive to the initial lag specification. Beginning with a lag length of one month and adding lags, the test reveals a lag of three months. On the other hand beginning with 38 months and dropping lags, the test reveals a length of 24 months. This ambiguity did not surface in any of the other periods we examined.

\section{Table 5}

The Relationship Between Changes in Money Growth and Changes in Interest Rates: January 1954 - December 1970

\begin{tabular}{|c|c|c|}
\hline Coefficient & Esinate & Arato \\
\hline Goistant & $1 / 43$ & 66 \\
\hline a. & 0.30 & 084 \\
\hline$a_{1}$ & 072 & 126 \\
\hline$a_{2}$ & $=080$ & 110 \\
\hline a & 0.43 & 055 \\
\hline 4. & 0.18 & 0.15 \\
\hline$a_{3}$ & 089 & 0,45 \\
\hline 2. & 492 & 2.16 \\
\hline 3) & 3.02 & 13.09 \\
\hline ar & 299 & 3.28 \\
\hline as & 267 & 286 \\
\hline 6. & 290 & 305 \\
\hline$a_{1}$ & 298 & 309 \\
\hline 61 & 2.10 & 2,13 \\
\hline a, & 199 & 205 \\
\hline a 4 & 189 & 1.980 \\
\hline$a_{1}$ & 214 & $20 \%$ \\
\hline$a_{16}$ & 2,39 & 262 \\
\hline artr & 210 & 236 \\
\hline$a_{8}$ & 220 & 250 \\
\hline a. & 220 & 252 \\
\hline 3. & 158 & 181 \\
\hline er & 128 & 159 \\
\hline (1) & 1078 & 105 \\
\hline$\beta_{3}$ & 065 & 14 \\
\hline aro & 024 & 0.61 \\
\hline $2 x$ & 3600 & 252 \\
\hline 9ho & 0.45 & 720 \\
\hline 9.81 & $1-1,92$ & $=187$ \\
\hline
\end{tabular}

$$
\begin{aligned}
& \text { Estimated Equation } \\
& \Delta_{t}=\text { Constant t. } ?_{k=0}^{24} a_{k} A M_{k}
\end{aligned}
$$

Comedred for first order autocomelation.

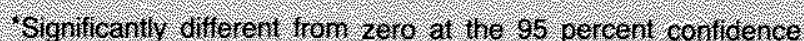
tovel

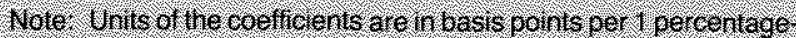
pain change in the nohthry ahulehed rate of change in the none stock 


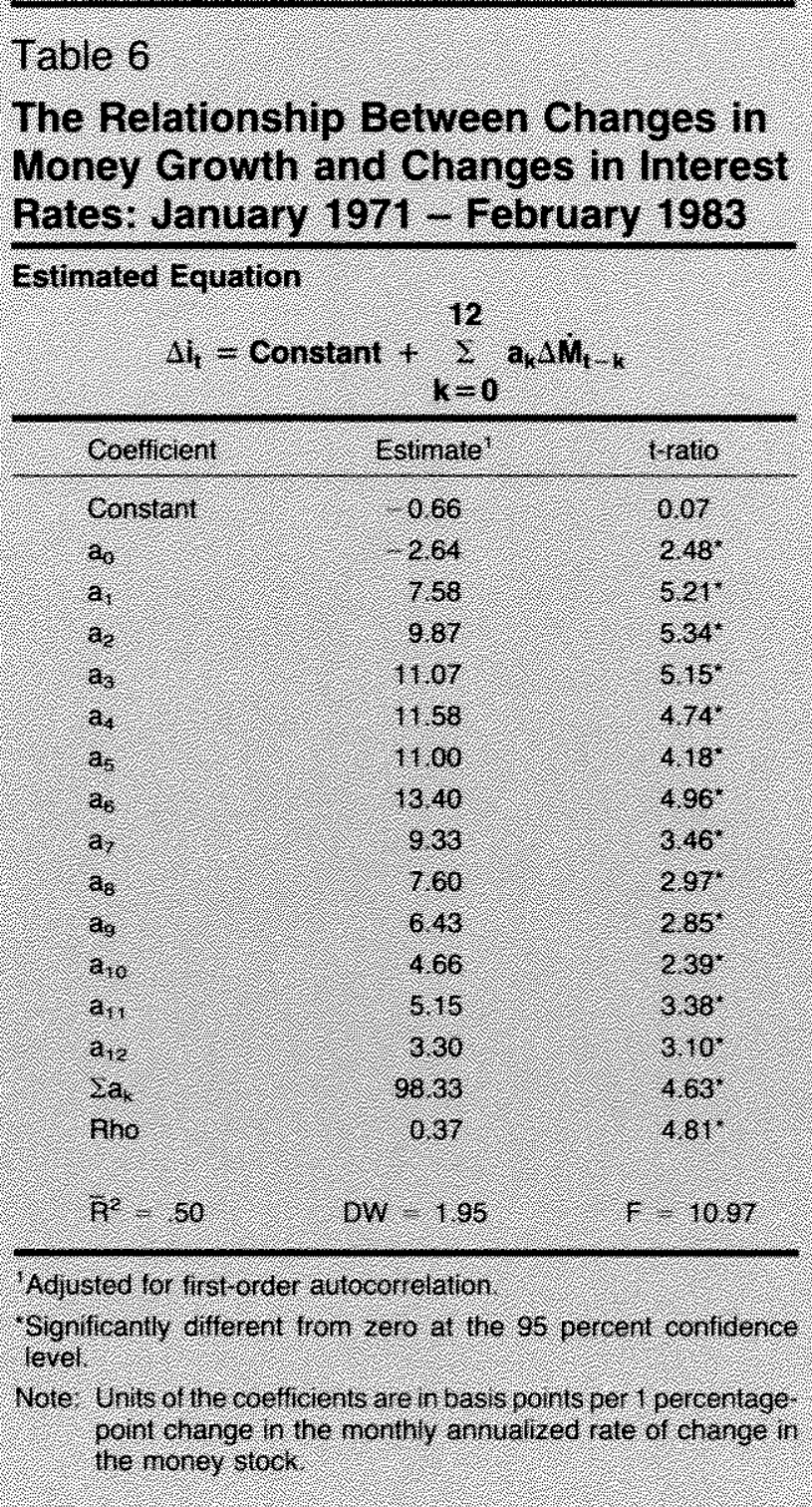

These results, with respect to both the incomplete adjustment of the nominal rate and the endogeny of money with respect to interest rates, can be explained by the operation of the Gold Reserve Act. Other explanations are no doubt possible. In any case, they reveal little about the lag in the effect of an exogenously determined monetary policy. In this sense, the results obtained for this period, as for the earlier periods, are disappointing.

\section{Jantary 1971- Tebrathy 1983}

Our results for the most recent period in which the dollar has been legally free from gold are summarized in table 6 . The F-test indicated a lag structure of 12 months. As before, the constant term is not significantIy different from zero. More important, the results are consistent with the existence of a contemporaneous liquidity effect. The coefficient of the contemporaneous change in the monetary growth rate is negative and significant. As expected, the liquidity effect is quite small numerically (2.65 basis points) and shortlived. ${ }^{23}$

The remaining coefficients are all positive and significant. The sum over the coefficients $(98.33$ basis points) is significantly different from zero and statistically indistinguishable from $100(t=.08)$ as predicted by the Fisher effect. Further, the bulk of the adjustment in the interest rate ( 61.86 basis points) takes place within six months.

Chart 1 illustrates the time path of the interest rate that is implied by these results. A comparison of chant 1 with figure 1 (panel $C$ ) indicates the results obtained for the more recent period conform roughly to those implied by rapidly changing inflation expectations. ${ }^{2-1}$

The Granger test for this period indicates bidirectional causality. On the whole, the results of the Granger test suggest that the January 1971-February 1983 period is the only one of those considered that is a candidate for a valid test of the hypothesis regarding the time path. It is only during this period that we cannot reject the hypothesis that changes in the monetary growth rate caused changes in the interest rate. ${ }^{25}$

\footnotetext{
${ }^{23} 1 \mathrm{~m}$ an effort to highight the licuidity effect that apparently occirs in the month contemporaneous to the change in monetary growth, we regressed Wednesday-to-Wednesday changes in the 3-month Treasury bill rate on the weekly change in the growth rate of the finally revised seasonally adjusted stock of M1. The contemporaneous and three lags of the monetary varible were induded as independent viriables. The data periods were $12 / 28 / 77-9 / 26 / 79$ and $10 / 3 / 79-10 / 6 / 82$. The period wats split in this fashion to control for the Fed's announced policy shift in October 1979 and its subsequent reversal in October 1982 . The results were disappointing in that a significant relationship failed to emerge in either stbperiod

${ }^{24}$ Earlier work on this question conduded that the lag was considerably longer than 12 months. See, for example, Cagan and Gandolfi, "The Lag in Monetary Policy," pp. 277-84

${ }^{25} \mathrm{All}$ of the tests were rum again with the corponate Aat bond rate identified as the dependent variable. Three important differences between these results and those for the commercial paper rate were noted. First during the gold standard period, the lag was 38 months. A statistically significant but very small liquidity effect (.76 basis points) energed. The Fisher effect again was zero. The results of the Gramger test indicate one-way causality runing fron money to Aala bond rates. Second, during the Jankary 1954December 1970 period, the lag was zero months. Neither liquid-
} 


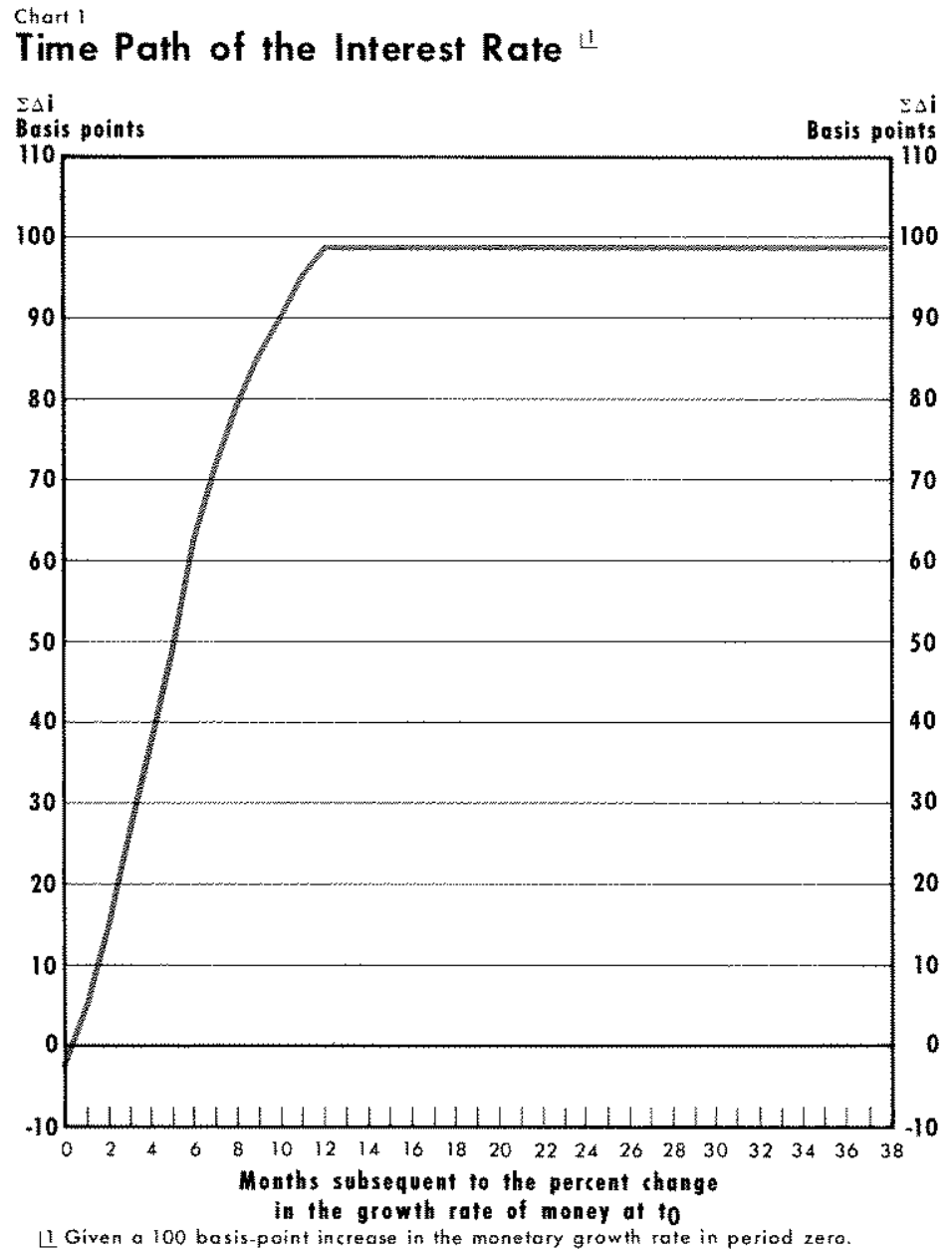

\section{SUMMARY AND CONOUUSTON}

A widely held view is that changes in the monetary growth rate operate on the nominal interest rate through systematically lagged liquidity and Fisher effects. In particular, increases in monetary growth are thought to produce initial declines and subsequent increases in the nominal and real rates of interest.

Our results suggest that only the data from the period since 1971 represent a fruitful basis for testing this hypothesis. Before then, the money and interest

ity or Fisher effects were apparent in the data. The Granger test indicates that money and Aa bond rates were independent series.

Third, during the January 1971 - February 1983 period, the lag is 12 months (consistent with that of the commercial paper rate). However, the data reject the appearance of a liquidity effect in nominal interest rates. None of the estimated coefficients are negative. Eleven coefficients are significantly positive but they sum to less than 100 basis points. The Granger test indicates bidirectional causality. rate data were either independent series or money was endogenous with respect to interest rates. When these subperiods are excluded from the sample, the shortterm nominal interest rate is observed to adjust completely to a change in the monetary growth rate with a lag of 12 months.

The monthly data for the most recent period reveal a statistically significant but economically anemic liquidity effect that dissipates rapidly. This was to be expected, given efficient financial and capital markets. On the other hand, the results concerning the Fisher effect are fairly strong. They suggest that an increase (decrease) in the monetary growth rate that persists for more than one month will result in an increase (decrease) in interest rates, other things constant. As a change in the monetary growth rate comes to be regarded as permanent, short-term rates will fully adjust within 12 months. The direction and magnitude of the change in short-term rates will mirror the change in monetary growth. 